\title{
The challenges for fair voice in liberal market economies
}

\author{
Mick Marchington and Tony Dundon
}

\section{Introduction}

The notion of fair voice sits centre stage in arguments about the relative importance of employee, organisational and societal goals because it connects directly with questions of managerial prerogative and social legitimacy. This creates tensions which are particularly apparent in liberal market economies (LMEs) - such as the UK, Australia, Ireland and New Zealand - where the law plays a relatively limited role in structuring workplace practice. In the case of the UK, following the decision to leave the EU in June 2016, it is uncertain whether the rhetoric and reality of fair voice will move further away from the EU social model. The notion of 'fair voice' is difficult to define because it does not relate to any one specific form of voice but can be seen through a variety of mechanisms, whether formal or informal, direct or representative. While some forms of representative participation might be seen as getting closer to achieving fair voice owing to the involvement of independent and effective trade unions, other forms of voice such as informal or individual channels may engage and involve workers in decisions and so achieve a degree of perceived fairness. An evaluation of 'fair voice' depends on who is asked, and when, about their level of participation. We return to this issue throughout the chapter.

This chapter draws upon the long-standing and distinctive academic contribution of Professor Jill Rubery by posing multiple challenges to the idea of 'fair' voice. This relates to her work in areas such as disorganised organisational hierarchies, feminisation, formal and informal labour market segmentation, flexibility and liberal market economic regimes. It reviews the notion of fair 
voice via a discussion of three key challenges. Firstly, it challenges simplistic definitions which treat fair voice as a uni-dimensional concept by showing how formal/informal and direct/representative practices operate beyond and within organisations in LMEs. These include European Works Councils (EWCs), partnership agreements, joint consultative committees (JCCs), problem-solving groups and informal interactions between line managers and staff, many of which operate alongside each other in large organisations. Also, the terms are elastic and debatable, subject to different interpretations by the principal actors: governments, employers and their organisations, trade unions, professional associations, HR and line managers, and employees. Secondly, it challenges the notion that employers have complete freedom to decide how to deliver fair voice. At an institutional level, so-called 'hard' national and transnational level forces shape voice through legislation (e.g. information and consultation or EWCs). Voice is also shaped by 'soft' forces - for example, by the Advisory Conciliation and Arbitration Service (Acas) or the Involvement and Participation Association (IPA) in the UK. At the intermediary level, lead bodies for employers and trade unions, professional associations, specialist bodies promoting partnership, management consultants and 'movements' such as Engage for Success have also captured space to promote specific forms of voice (Marchington, 2015a). Thirdly, it explores challenges to fair voice at the organisational level where formal practices can be undermined by managerial preferences for informal voice which is difficult to sustain. Moreover, contracting-out, agency work and multi-employer partnerships make it difficult to identify the employer at many workplaces, further fragmenting efforts to achieve fair voice (Marchington et al., 2005).

\section{Challenges of definition: meanings and interpretations of fair voice}

The range of terms used to describe employee voice makes it a highly debatable concept. For many managers, 'information-sharing' or 'communications' are regarded as normal and legitimate, symbolising fair expectation. However, for trade union officials, and even government policy advisors, labels such as 'participation', 'consultation' and 'bargaining' constitute voice systems. Much depends on context: size of the employer, labour and product markets, occupational mix, different management styles, inter-organisational relationships and whether or not the labour force is unionised. The choice of which practices to adopt is shaped by the degree of power and influence exercised by different actors. Negotiation, for example, implies mangers agree to relinquish 
some of their prerogative when they negotiate and make agreements with union officials representing the interests of workers. Employee involvement, on the other hand, may seek ideas but the final decision remains with management. Given these different interpretations and approaches, we define employee voice broadly, following Boxall and Purcell (2011: 162), as incorporating a range of mechanisms 'which enable, and at times empower employees, directly and indirectly, to contribute to decision-making'.

Further meanings arise when considering employee voice in international terms. For instance, in many European countries, statutory rights suggest a more equal or fairer system for employees to have a say on matters that affect them, such as via EWCs. In other liberal market countries however, such as the USA or Australia, there is limited emphasis on statutory provisions for fair voice, so much depends on managerial prerogative, union bargaining power or the role of other institutional actors. But things also vary between European countries and voice can be tailored to fit national customs and cultures. In the UK and Ireland, for instance, the content of the European Directive for Employee Information and Consultation (the ICE Directive) has been transposed with minimal regulatory power and enforcement (Hall et al., 2013). While the European ICE Directive explicitly called for indirect forms of employee voice with elected representatives, the transposed UK and Irish regulations allow for direct and individual channels of communication and information-sharing (Dobbins et al., 2016).

The meanings of voice can further differ depending on the presence or absence of a trade union. It is common for non-unionised companies to use the terms 'empowerment' and 'communications', even when they utilise representative forums such as EWCs (Ackers et al., 2004). In Britain, the Workplace Employment Relations Study (WERS) surveys indicate that the majority of managers generally prefer to consult with workers in more direct than indirect ways: only 10 per cent of all workplaces use a combination of both representative and direct forms of voice, while 37 per cent of establishments use neither of these methods (van Wanrooy et al., 2013: 66).

There are two underlying philosophical perspectives that can help conceptualise fairness in relation to voice. First is the idea of political citizenship where fairness relates to ideas derived from societal democracy. Hyman (2015: 12) has observed that one cannot justify the notion of a 'free citizen in the public sphere but a slave in the workplace'. Rights and access to voice as a citizen of a democratic country, say in political elections or referenda, do not end inside the factory or workplace. In this context, fair voice is seen as a fundamental human right and the principle of having an input on decision-making at workplace level is as legitimate as voting in political elections. A second perspective assesses 
how fair voice relates to economic efficiency ideas. The argument here is that allowing workers and/or their representatives to contribute to management decisions may encourage higher levels of commitment and ultimately better performance (Marchington et al., 2016). Some forms of voice, such as partnership, draw upon both approaches, but 'patrimonial capitalism' (Piketty, 2013) allows managerial decision-making to take place beyond independent scrutiny, thus providing a further challenge to the concept fair voice.

One way of addressing the challenge is to specify voice with informed precision, using a fourfold schema including the 'degree', 'level', 'scope' and 'form' of the mechanisms used in practice (Wilkinson et al., 2013). Degree is central to ideas of fair voice, as it captures the extent to which employees have a genuine or influential say about organisational matters that concern them (Marchington et al., 2016). A stronger degree occurs when employees, either directly or indirectly, can influence decisions traditionally reserved for management. By contrast, a diluted degree of fair voice is evident when employees have little or no say, perhaps merely being informed by management of their decisions. Second is the level at which voice occurs, covering a small work unit, department, division or company but this is based on judgements about the appropriate level to make decisions. For example, asking all employees for a detailed input about new corporate investment plans would be too far-removed from employees' day-to-day matters, though it would offer an opportunity for fair voice if workers representatives were involved via EWCs or JCCs. Likewise, deciding to restructure a team or department without any input from front-line managers or employees would be unfair for those most likely to be affected by the decision. Third is the scope of voice, which relates to the issues on which workers or their representatives are involved. Scope can range from relatively minor work task issues to more substantive employment conditions outcomes; for example, involvement in procedures to ensure equal pay or promotion criteria may signal wide scope and potentially fairer voice opportunities (Rubery and Fagan, 1995; Rubery, 2015a).

There are three main forms of voice. First is representative voice, where employee voice is indirect and heard through formal bodies such as trade unions, JCCs, negotiating committees and employee forums. This category is typically high in degree and wide in scope, providing opportunities for employee representatives to discuss issues with managers, or where collective bargaining exists to negotiate terms and conditions of employment. Second is direct voice, where individual employees receive information and have a say through mechanisms including team briefing or problem-solving groups, suggestion schemes, engagement surveys or social media platforms, which have all become more widespread in LMEs (Marchington, 2015a). Direct voice may be fair or not, depending 
on the scope and depth of a particular mechanism. For example, Rubery and Fagan (1995) recognised the issue of gender blindness in employment relations systems, including voice and participation, pointing out that many sections of the labour force can be marginalised or silenced. At the same time, however, individualised direct channels may offer new avenues for voice as front-line managers are allowed to provide opportunities for team members to offer ideas (Cox et al., 2009). Third is informal voice, which has been seen as either a substitute for or a supplement to formal voice mechanisms (Marchington and Suter, 2013). It includes ad hoc interactions between front-line managers and employees, typically sharing information and ideas through conversations. Research across LMEs indicates that informal voice is important not just in small firms, where formal mechanisms are less prevalent, but also in larger organisations (Marchington, 2015b). Informal dialogue may be an important lubricant to fair voice as communications are seen as friendly and regular, adding to a broader engagement culture where processes are often regarded as more important than formal structures (Schaufeli, 2014). However, as Purcell (2014: 251) notes, much of the engagement literature ignores the strong-established connections between voice and fairness, justice and trust, preferring to focus primarily on organisational performance.

This demonstrates voice is more complex than a straightforward continuum from no involvement (information) to extensive workforce involvement (control). The extent to which voice practices are perceived as fair depends on the degree to which they are embedded, the ways in which they overlap, the scope of topics covered and the level at which voice decisions are taken. However, there are also challenges from beyond the workplace in how hard and soft regulatory and intermediary forces shape fair voice.

\section{Challenges for fair voice from beyond organisations: hard, soft and intermediary forces}

\section{The role of 'hard' institutional forces in shaping voice at organisational level}

Most of the literature examines voice at the organisational level. To varying degrees, factors of interest tend to include product and labour markets, organisation size, culture, management choice, and union or non-union structure (Marchington, 2007). Unfortunately, as Rubery (2015b) notes, these studies tend to ignore how regulatory institutions can shape voice practices for more inclusive labour markets. Furthermore, Rubery and Grimshaw (2003) point 
out that these institutions in different countries can constrain and reconfigure employer choice about employment policy and practice. As such, the perceived fairness of voice can be facilitated or undermined in LMEs by the application of employment laws or by national business systems operating within a country. In short, institutional structures and systems do matter.

In comparison with coordinated market economies (CMEs), 'hard' institutional forces have a lesser role in shaping mandated voice rights in the UK, Australia, New Zealand, Ireland and the USA. Dundon and colleagues (2014: 9) report that at a transnational EU policy level, lobbying from employers and employer bodies, such as the US Chambers of Commerce, has been successful in influencing employee information regulations before wider and formal public consultations. In particular, employers were able to persuade policy agencies to support information obligations via direct voice rather than wider collective representative bargaining channels for ICE. At national levels the situation was similar to the minimalist rights to fair voice found at the transnational - European Union (EU) - level. In Ireland, for example, the harder EU regulations for voice were transposed with a conscious 'light-touch' impact on employer obligations (Dobbins et al., 2016). In the UK, laws that support employees to receive information and be consulted by their employer were perceived by Taylor and colleagues (2009) to constitute little more than 'an umbrella full of holes', broadly compatible with other concerns about the future of the UK's tradition of liberal collectivist forms of employment regulation (Grimshaw and Rubery, 2012).

However, light-touch regulation does not imply totally unfettered free choice for employers (Edwards et al., 2007). In the UK, worker participation was shaped partly by public policy for representative voice which reflected government views on best practice partnership (Ackers, 2010: 69). In Ireland, voluntary rather than statutory partnership was endorsed by government policy with evidenced gains for workers and unions (Geary, 2008). Moreover, legislation on ICE and EWCs means some employers in LMEs are bound by statutory laws that mandate certain forms of voice. Both Hall and Purcell (2012) and Marchington (2015a) found that where large employers in the UK had used JCCs and/or partnership forums for some time, they were quite comfortable with these arrangements and open to EWCs if they had locations in several EU countries. In Australia, too, the Federal Court has powers to fine employers for failing to consult workers properly. However, when institutional support is withdrawn or seen as partial, incentives to maintain existing forms of voice can dissipate if government and employer support is lukewarm (Roche and Teague, 2014).

Consequently, minimalist 'hard' institutional forces have a limited impact on managerial choice, which raises questions about the extent of fair voice for employees across LME regimes. Any specific impact on direct and informal 
voice is likely to be minimal because these forms of engagement are not included in legislation, but 'hard' institutions can shape representative voice, particularly EWCs and some ICE forums, if the organisations concerned fall within the remit of statutory laws. The limited impact of fair voice can further be reinforced by national business systems which promote flexible labour markets and privilege choice, informality and light-touch regulation. As such, while 'hard' institutional forces can influence the take-up of representative voice they cannot shape the fairness of the processes accompanying it, and thus in themselves may not be able to address the challenges to fair voice. The impact of ICE in the UK and Ireland showed that 'hard' institutional forces were treated in 'a reluctant and halfhearted manner' by employers, who - while implementing voice forums within their own businesses - traditionally favour the primacy of flexibility and choice within a voluntarist employment relations regime (Hall et al., 2013).

\section{The role of 'soft' institutional forces in shaping voice at organisational level}

Given the limited direct impact of 'hard' institutional laws mandating worker voice in LMEs, perhaps 'softer' institutional forces designed to improve voice, employee well-being and organisational performance by supporting partnership, engagement and workplace cooperation stand a better chance of being adopted because they are better aligned with the voluntarist traditions in these countries. These take two broad forms:

(1) Specific 'soft' institutional initiatives funded by government, designed to embed workplace partnership, have been tried in the UK, Ireland, Australia and New Zealand since the mid-1990s. These can be regarded as 'soft' because they do not compel employers to implement specific voice mechanisms but rather persuade them to adopt the principles of mutuality (Stuart et al., 2011). Consequently, this type of voice is assumed, in the LME context, to have more chance of being implemented at organisation level because it is seen as less rigid by senior managers and employers. However, it is susceptible to collapse, especially when economic conditions deteriorate and/or political power struggles in government change priorities because they are not enshrined in law.

(2) Longer-standing government and other semi-autonomous organisational schemes that may help lubricate fairer voice on a voluntary basis continue to figure prominently in LMEs. Examples include Acas in the UK and the Workplace Relations Commission (WRC) in Ireland, ${ }^{1}$ both of which publish codes of practice and information sheets, as well as run seminars for practitioners which can be seen to promote fairer systems for voice. For example, Stuart and colleagues (2011) demonstrate how Acas officials played a key role in helping to support partnership and workplace cooperation. Moreover, because they 
build trusting networks with practitioners over time, their ideas for voice have a greater chance of acceptance. As with Rights Commissioners in Ireland and Fair Work Commissioners in Australia, officials and advisors are recognised as 'impartial, objective and independent' which adds legitimacy to their role and influence - unlike private consultancy firms which are typically hired by management and openly biased towards employer views (Stuart et al., 2011: 3802).

'Soft' institutional forces have shaped representative and direct voice at organisational level in Australia and New Zealand because managers and unions were willing recipients of the advice offered. The scope of voluntary support also seemed to allow a degree of flexibility which appealed to employers. However, as many voice initiatives were relatively short-lived, the longevity of fairness for employees or impact across the whole economy remained in some doubt (Marchington, 2015b). Similarly, in Ireland, many workplace partnerships were endorsed as exemplar best-practice models by the state institution, the National Centre for Partnership and Performance (NCPP). In these cases, however, as economic uncertainty increased, cooperative forms of engagement faltered despite the good intentions among managers, employees and unions (Dobbins and Dundon, 2016). Several factors exposed the limitations of softer institutions supporting representative voice. For example, local managers had difficulty sustaining collaborative initiatives and fulfilling employee expectations for fair voice, often owing to external economic pressures that were beyond their control and that of the supportive state institutions. In addition, senior managers at multinational HQs used their influence to constrain local managerial discretion for partnership arrangements. While some semi-autonomous state institutions provided a lubricant for voice by maintaining networks of trust between employers and trade unions and helped to mediate issues and tensions, in others the impact on employers was less significant and the longevity of fair voice constrained owing to external economic and political pressures.

\section{The role of intermediary forces in shaping voice at organisational level}

Given that LMEs traditionally have highly deregulated systems for employee voice, it is surprising to find so little interest in the role of intermediary forces which operate between government and employers, independent of both. As Edwards and colleagues (2002: 6) note, 'there remains a large gap (the missing middle) between public policy and what happens on the ground, and the opportunity to narrow it should be grasped'. These 'intermediary forces' include employers' organisations, professional associations and other bodies with a specialist interest in voice and engagement. 
Many employers' organisations provide advice and support to promote voice that may not otherwise exist among their members. Both the Confederation for British Industry (CBI) in the UK and the Irish Business and Employers' Confederation (IBEC) support voluntary voice practices, particularly direct and informal voice, and many members have EWCs or other forms of representative voice. The Chartered Institute of Personnel and Development (CIPD) has had a strong interest in voice for many years, funding research, running an annual UK conference, advising members about the potential impact of EU legislation as well as contributing to the Employee Engagement Task Force and the IPA Council. The CIPD believes a flexible approach which fits with organisational needs is most appropriate, including representative voice where trade unions or staff associations exist. These ideas are disseminated to HR specialists via national and local presentations, research reports from CIPD-funded projects (e.g., Alfes et al., 2010; Dundon et al., 2004) and its monthly magazine. The CIPD Ireland branch also held a research conference on employee engagement (Hickland, 2011). While the potential for the CIPD to shape voice practices is potentially sizeable, it is hard to be precise about its contribution because ideas are diffused through a range of different channels. In addition, the IPA has had a specific interest in employee voice for many years, including its role in promoting partnership and representative participation.

Not all intermediary bodies have a 'permanent' presence but they can still influence the implementation of voice. A good example here is Engage for Success in the UK, which has received support from government to make employee engagement more visible (see also MacLeod and Clarke, 2009). It is funded by members, either by seconding staff or providing technical expertise, though whether it will remain a key part of the voice agenda or merely be the latest fad and fashion in management thought is contested (Guest, 2014). Marchington's (2015a, b) research demonstrated that in some UK and Irish organisations, employee engagement went way beyond surveys to include training opportunities for all staff, organisational change programmes and, in relation to fair and independent voice, employee champions drawn from the workforce to sit on key committees. For example, one large, highly unionised firm had set up a system of workplace teams which had autonomy to identify work improvements within the context of a strong representative voice structure. Engage for Success encourages organisations to create dedicated programmes by drawing upon ideas from across the network but adapting them to suit their own organisation context.

While intermediary forces can shape representative voice, they are more likely to influence direct and informal voice; the latter in particular fits well with the discourse of flexibility and voluntarism associated with LMEs. Before moving to the next section, two points need to be reiterated. Firstly, in LMEs 
with light-touch regulation all forms of voice are susceptible to break down if they have not been well-embedded with other organisational HR practices; if they become susceptible to economic or political change factors; or if they are perceived as unfair by employees or unions (Dobbins and Gunnigle, 2009). Such fragility is likely to be even more prevalent for informal voice (Marchington, 2015b). Intermediary forces are potentially unstable because they are not enshrined in law but rely on flexible business systems and neoliberal political ideologies. Secondly, fair (and successful) voice initiatives tend to be copied by other organisations, either directly or via consultants, and thus spread more widely. Accordingly, the process of transfer is not solely one-way from intermediary level to organisations but also takes place internally, particularly among foreign-owned multinational corporations (MNCs) (Lavelle et al., 2010).

It appears that 'hard' and 'soft' institutional and 'intermediary' forces are active across LMEs, though their role varies between countries, as Table 5.1 shows. This draws on research by Marchington (2015b) and Dobbins and Dundon (2016) to show that 'hard' regulations shape patterns of representative voice more than they do direct forms. Intermediary institutional forces are important for representative voice in different economic regimes (Rubery and Grimshaw, 2003), though the impact is confined to the organisations actively involved in such initiatives and institutional arrangements. The contribution of intermediary forces to fair voice is harder to evaluate given their primary target on direct and informal voice, both of which can lack underpinning independent, formal structures.

\section{Challenges for fair voice at the organisational level}

\section{Front-line managers and informal voice}

While some would argue that fair voice is only achievable through independent trade unions representing their members through high-level committees such as EWCs, it could be argued that these are not sufficient on their own to embed voice effectively at workplace level (Wilkinson et al., 2013). Indeed, for many years unions have not been good at including the voices of women and ethnic minorities, although recent strategies have been designed to correct the gender representation gap with specific committees to input union decision-making (Kirton, 2015). Fair voice might well rely on a mix of practices at different levels, including the opportunity for workers to raise issues directly with their 
Table 5.1 External forces shaping voice policy and practice

\begin{tabular}{|c|c|c|}
\hline $\begin{array}{l}\text { Forces } \\
\text { shaping } \\
\text { voice }\end{array}$ & $\begin{array}{l}\text { Components of forces } \\
\text { shaping voice }\end{array}$ & Forms of voice shaped by forces \\
\hline $\begin{array}{l}\text { 'Hard' } \\
\text { institutional } \\
\text { forces }\end{array}$ & $\begin{array}{l}\text { Legal regulation via EU laws and } \\
\text { directives in UK and Ireland, } \\
\text { and federal Court in Australia } \\
\text { National business system in each } \\
\text { country supports voluntary } \\
\text { light-touch regulations for } \\
\text { voice }\end{array}$ & $\begin{array}{l}\text { Representative voice at organisations } \\
\text { covered by these regulations } \\
\text { Direct and informal voice plus } \\
\text { employee engagement }\end{array}$ \\
\hline $\begin{array}{l}\text { 'Soft' } \\
\text { institutional } \\
\text { forces }\end{array}$ & $\begin{array}{l}\text { Government-funded initiatives } \\
\text { Semi-autonomous government } \\
\text { activities }\end{array}$ & $\begin{array}{l}\text { Representative and direct voice, } \\
\text { typically limited to those actively } \\
\text { involved in initiative } \\
\text { All forms of voice to some extent, but } \\
\text { especially direct and informal voice }\end{array}$ \\
\hline $\begin{array}{l}\text { Intermediary } \\
\text { forces }\end{array}$ & $\begin{array}{l}\text { Employers organisations (and } \\
\text { trade union federations) } \\
\text { Professional associations } \\
\text { Organisations specialising in } \\
\text { voice and engagement }\end{array}$ & $\begin{array}{l}\text { Some representative forms of voice, } \\
\text { but more the promotion of direct, } \\
\text { flexible and informal voice } \\
\text { Direct and informal voice but also } \\
\text { representative voice if already exists } \\
\text { Direct and informal voice, } \\
\text { employee engagement and some } \\
\text { representative voice }\end{array}$ \\
\hline
\end{tabular}

front-line manager at any time. Because blockages can occur within managerial and union hierarchies, informal voice may fill some of these gaps.

Evidence suggests that workers like informal voice as it gives them a chance to engage directly with front-line managers. Some find it easier to communicate with their front-line managers on a one-to-one basis because they are nervous about speaking in large groups (Marchington and Suter, 2013). Informal dialogue may provide a conduit to fairer voice from the perspective of employees because this allows workers to hear about new developments and provides them with an opportunity to discuss matters immediately at a level which is directly relevant. As Purcell and Georgiadis (2007: 197) note, 'employers who want to gain the maximum value from voice systems would do well to note that all the evidence points to the need for direct face-to-face exchange with employees at their work stations and in groups'. Similarly, in organisations with formal non-union employee representation (NER) committees, some employees found their immediate supervisor more responsive to their needs and tended 
to raise concerns with line managers rather than utilising formal NER channels (Cullinane et al., 2014). Dundon et al. (1999: 262) found that informal communications at workplace level helped ameliorate some of the harsher working conditions felt by employees in small firms; in particular, informal voice facilitated friendly relations among co-workers and gave garage mechanics work satisfaction because they could discuss technical challenges and speak directly with customers. Informal voice can also be attractive to front-line managers because research indicates that informal chats account for the vast majority of what they learn about employee feelings, and it also gives them the chance to discuss issues directly with workers and offers some choice about whether or not to accept or modify employee ideas for improvement (Marchington and Suter, 2013). However, as we have already suggested, informal interactions alone are unlikely to achieve fair voice without clear underpinning from formal practices and a strongly stated commitment from senior managers that workers' ideas and contributions are vitally important.

\section{Accessing fair voice across organisational boundaries}

The way in which employee voice practices operate across organisational boundaries at multi-employer workplaces raises even greater challenges for fair voice because authority, power and trust can be further undermined by added layers of subcontracting and multiple contracts. Several Manchesterbased research projects (e.g. Grimshaw et al., 2010; Marchington et al., 2005; Rubery and Urwin, 2011) provide evidence that workers employed across organisational boundaries enjoy less voice than their in-house colleagues at the same workplace. In short, 'non-citizen' workers in these contexts experience a double whammy. They suffer not just from the usual hazards that arise from being the weaker party to a traditional employment contract, but also from the additional risks of having their work governed by commercial contracts over which they have no influence and whose systems offer them little or no opportunity for voice.

This is especially problematic for workers employed for relatively short periods of time at a particular site, such as agency supply teachers (Hebson et al., 2003). In such situations, agency workers can move between establishments regularly, consequently feeling little identification with or involvement in issues at the host organisation. Missing out on vital pieces of information limits the opportunity to contribute to discussions about work organisation, with or without unions having an active presence. Accordingly, fair voice can be found wanting when the proportion of contracted workers is small since they can easily be overlooked or regarded as not important enough to be included in communications 
available to employees at the host organisation. Moreover, if there is resentment to 'external' (agency) workers, perhaps because they are employed on lower rates of pay or are felt to have taken jobs from 'internal' workers, their chances of being included in formal and informal voice are also reduced (Marchington et al., 2005). Moreover, agency and subcontract workers based at a host organisation can also miss out on more formal opportunities to participate - such as in-house suggestion schemes or JCCs - because they are not actually 'employees' and managers may be reluctant to share confidential data with people who are seen as peripheral or regarded as having little commitment to the host employer.

A slightly different scenario occurs at large, multi-employer sites - such as airports or hospitals - where people are employed by many different organisations on a range of employment contracts, even though they are all aiming to provide an integrated and holistic service for customers (Grimshaw et al., 2010; Rubery et al., 2003). At the same time, each organisation has competing priorities, a multiplicity of different management styles and occupational mixes which result in the emergence of representative, direct and informal voice practices that lack integration, consistency and alignment. The case-study research tradition has been particularly insightful in unpacking the tensions and ambiguities of fairness, voice and employment equity issues.

Although mechanisms of representative and union participation have declined over recent decades in LME regimes such as the UK (van Wanrooy et al., 2013), the implementation of statutory information and consultation arrangements has had a mixed response. At one level, the idea of regulatory support reinvigorated interest in representative voice at the workplace, while at another trade unions have largely vacated the regulatory space for voice, perhaps seeing Europeanstyle employee information rights as a back-door form of non-union voice (Hall et al., 2013). While EWCs, JCCs and some NERs offer employees some say in matters that affect them and their work, the barriers for those on the periphery of the employment relationship - agency and outsourced workers, and those working in public-private partnerships - can result in a lower level of access to these voice institutions than for those working for the dominant employer in these relationships. Worse still, in the case of statutory works councils, flexible workers have no legal recourse to collective representation. Similarly, in terms of outcome, in the case of JCCs or other voluntarist NER forums in the UK and elsewhere, agency workers can be proactively excluded by managers as well as core employees. 


\section{Conclusions}

As we noted in the introduction, this chapter is part of a celebration and recognition of the academic career of Professor Jill Rubery. Many of her contributions - often in conjunction with other long-standing Manchester researchers such as Goodman, Marchington and Grimshaw - have instigated and extended key debates about labour market regulations and institutions that shape voice and other aspects of employment relations. Ackers (2010) analyses the way in which these research trajectories shaped numerous investigations into labour markets over the last 30 years. Rubery, in different ways, discredited the populism of a new right political agenda of free market managerialism while questioning materialist traditions of economic Marxism as a source of realistic social change amidst restructured labour markets, blurred organisational boundaries and flexible and feminised employment patterns (Marchington et al., 2005; Rubery, 2015b). A body of research brought centre stage the voices of many of those who had become marginalised and disenfranchised from access to fair voice (e.g. low-paid workers, women, agency and outsourced workers, those in precarious jobs, and part-time and casualised contract employees). This work has added an important gendered and, more recently, intersectional focus to the study and analysis of fairness surrounding employment issues, particularly pay, working hours and skill, but also voice and representation in comparative context (Hebson and Rubery, 2017).

We acknowledge it is difficult to define, develop and sustain fair voice. Regulation, such as the Organisation for Economic Co-operation and Development's 2012 objective to promote 'better regulation' (OCED, 2012), is usually advanced as one way to ensure fairness, but the future prognosis for more or better regulation seems unlikely in LMEs. Opportunities for fair voice do exist but there are also multiple challenges to its development and sustainability in LMEs, particularly the waves of light-touch regulation minimising deeper forms of voice. A contemporary pragmatic challenge for fair voice, at least among large UK and UK-based MNCs, is what to do post-Brexit. One response might be an extension of individualism alongside light-touch regulation as part of a continued neoliberal system. A consequence of this might be further individualisation and flexibility for voice shaped by managerial prerogative, without the checks and balances of a European social model for fairer voice. However, the agency influence of employers, unions and other soft institutions may reconfigure the agenda for fair voice to some extent in a post-Brexit world. For example, managers may opt to support the institutional arrangements for representative voice such as JCCs and EWCs, particularly if these 'fit' with 
the organisation's business objectives. This might provide the opportunity for employers to embed the importance of fairness, justice and best-practice efficiency by signalling to employees and stakeholders the value of voice as a fundamental right and a major contributor to employee well-being.

In celebrating Rubery's career, this chapter has posed multiple challenges to the promotion of fair voice in LMEs within the context of global labour market restructuring. As we mention, the very concept of fairness is of course debatable. Important insights to such debates have been advanced from both the 'casestudy' research tradition and the use of 'comparative international analysis' used by Rubery (and others) in teasing out the complexities of work and the sources of power, equality and inequality in employment systems (see Beynon et al., 2002; Karamessini and Rubery, 2013; Marchington et al., 2005). Whether voice is seen as fair or not is shaped to a significant degree by forces at different levels: hard and soft regulations, intermediary market institutions, fragmented organisational structures and informal workplace relationships. These forces all play a role in undermining or blurring the impact of formal systems of fair voice within employing organisations, particularly for those workers on the periphery of the labour market. Our contention is that fair voice is a legitimate and valuable goal, irrespective of measures of performance, although without harder regulations for worker rights, the achievement of fairness may remain fuzzy and elusive, particularly in a more uncertain post-Brexit world.

\section{Note}

1 The WRC was formed in 2016 from previous state agencies, including the former Labour Relations Commission (LRC), Rights Commissioners and Equality Authority.

\section{References}

Ackers, P. (2010), 'An industrial relations perspective on employee participation', in Wilkinson, A., Gollan, P., Marchington, M., and Lewin, D. (eds), The Oxford Handbook of Participation in Organisations (Oxford: Oxford University Press).

Ackers, P., Marchington, M., Wilkinson, A. and Dundon, T. (2004), 'Partnership and voice, with or without trade unions: changing UK management approaches to organisational participation', in Stuart, M. and Martinez Lucio, M. (eds), Partnership and Modernisation in Employment Relations (London: Routledge).

Alfes, K., Truss, C., Soane, E., Rees, C. and Gatenby, M. (2010), Creating an Engaged Workforce: Findings from the Kingston Employee Engagement Consortium Project (London: CIPD). 
Beynon, H., Grimshaw, D., Rubery, J. and Ward, K. (2002), Managing Employment Change: The New Realities of Work (Oxford: Oxford University Press).

Boxall, P. and Purcell, J. (2011), Strategy and Human Resource Management, 3e (London: Palgrave).

Cox, A., Marchington, M. and Suter, J. (2009), 'Employee involvement and participation: developing the concept of institutional embeddedness', International Journal of Human Resource Management, 20:10, 2150-68.

Cullinane, N., Donaghey, J., Dundon, T., Dobbins, T. and Hickland, E. (2014), 'Regulating for mutual gains: non-union employee representation and the Information \& Consultation Directive', International Journal of Human Resource Management, 25:6, 810-28.

Dobbins, T. and Dundon, T. (2016), 'The chimera of sustainable labour-management partnership’, British Journal of Management. doi: 10.1111/1467-8551.12128

Dobbins T. and Gunnigle P. (2009), 'Can voluntary workplace partnership deliver sustainable mutual gains?', British Journal of Industrial Relations, 47:3, 546-70.

Dobbins, T., Dundon, T., Cullinane, C., Hickland, E. and Donaghey, J. (2016), 'Employment regulation, game theory, and the lacuna in employee participation in liberal economies', International Labour Review. doi: 10.1111/j.1564-913X.2015. 00053. $\mathrm{x}$

Dundon, T., Grugulis, I. and Wilkinson, A. (1999), 'Looking out of the Black-Hole: nonunion relations in an SME', Employee Relations, 22:3, 251-66.

Dundon, T., Wilkinson, A., Marchington, M. and Ackers, P. (2004), 'The meaning and purpose of employee voice', International Journal of Human Resource Management, 15:6, 1149-70.

Dundon, T., Dobbins, T., Cullinane, N., Hickland, E. and Donaghey, J. (2014), 'Employer occupation of regulatory space of the Information and Consultation (I\&C) Directive in liberal market economies', Work Employment and Society, 28:1, 1-19.

Edwards, P., Gilman, M., Ram, M. and Arrowsmith, J. (2002), 'Public policy, the performance of firms, and the "Missing Middle": the case of employment regulations and a role for business networks', Policy Studies, 23:1, 5-20.

Edwards, T., Collings, T. and Ferner, A. (2007), Conceptual approaches to the transfer of employment practise in multinational companies: an integrated approach', Human Resource Management Journal, 17:3, 201-17.

Geary, J. (2008), 'Do unions benefit from working in partnership with employers? Evidence from Ireland'. Industrial Relations, 47:4, 530-68.

Guest, D. (2014), 'Employee engagement: fashionable fad or long-term fixture?', in Truss, C., Delbridge, R., Alfes, K., Shantzm A. and Soane, E. (eds), Employee Engagement: Theory and Practice (Abingdon: Routledge).

Grimshaw, D. and Rubery, J. (2012), 'The end of the UK's liberal collectivist social model? The implications of the coalition government's policy during the austerity crisis', Cambridge Journal of Economics, 36:1, 105-26.

Grimshaw, D., Rubery, J., and Marchington, M. (2010), 'Managing people across hospital networks in the UK: multiple employers and the shaping of HRM', Human Resource Management Journal, 20:4, 407-23. 
Hall, M., Hutchinson, S., Purcell, J., Terry, M. and Parker, J. (2013), 'Promoting effective consultation? Assessing the impact of the ICE Regulations', British Journal of Industrial Relations, 51:2, 355-81.

Hall, M. and Purcell, J. (2012), Consultation at work: Regulation and practice (Oxford: Oxford University Press).

Hebson, G., Grimshaw, D. and Marchington, M. (2003), 'PPPs and the changing public sector ethos: case study evidence from the health and local authority sectors', Work, Employment and Society, 7:3, 483-503.

Hebson, G. and Rubery, J. (2017), 'Employment relations and gender equality', in Wilkinson, A., Dundon, T., Donaghey, J. and Covin, A. (eds), Routledge Companion of Employment Relations (Abingdon: Routledge).

Hickland, E. (2011), 'Retail Co - employee voice and engagement: case study evidence \& reflections', Paper presented to Chartered Institute of Personnel and Development Research Symposium on 'Employee Voice and Engagement: Establishing the Link and Exploring the Evidence of Policy and Practice in Ireland', Galway, November.

Hyman, R. (2015), 'The very idea of democracy at work', Transfer: European Review of Labour and Research, 22:1, 11-24.

Karamessini, M. and Rubery, J. (eds) (2013), Women and Austerity: The Economic Crisis and the Future for Gender Equality (Abingdon: Routledge).

Kirton, G. (2015), 'The Coalition of labor union women: still a space of social creativity and a force for social change', Labor Studies Journal, 40:2, 129-48.

Lavelle, J., Gunnigle, P. and McDonnell, A. (2010), 'Patterning employee voice in multinational companies', Human Relations, 63:3, 395-418.

MacLeod, D. and Clarke, N. (2009), Engaging for Success: Enhancing Performance through Employee Engagement (London: Department for Business, Innovation and Skills).

Marchington, M. (2007), 'Employee voice systems', in Boxall, P., Purcell, J. and Wright, P. (eds.), The Oxford Handbook of Human Resource Management (Oxford: Oxford University Press).

Marchington, M. (2015a), 'The role of institutions and intermediary bodies in shaping patterns of employee involvement and participation (EIP) in Anglo-American countries', International Journal of Human Resource Management, 26:20, $2594-616$.

Marchington, M. (2015b), 'Analysing the forces shaping employee involvement and participation (EIP) at organisation level in liberal market economies (LMEs)', Human Resource Management Journal, 25:1, 1-18.

Marchington, M., Grimshaw, D., Rubery, J. and Willmott, H. (eds) (2005), Fragmenting Work: Blurring Boundaries and Disordering Hierarchies (Oxford: Oxford University Press).

Marchington, M. and Suter, J. (2013), 'Where informality really matters: patterns of employee involvement and participation in a non-union firm', Industrial Relations, 52:S1, 284-313.

Marchington, M., Wilkinson, A., Donnelly, R. and Kynighou, A. (2016), Human Resource Management at Work, 6e (London: Chartered Institute of Personnel and Development).

OECD (Organisation for Economic Co-operation and Development) (2012), Better Regulation in Europe - the EU 15 project, http://www.oecd.org/gov/regulatory-policy/ betterregulationineurope-theeu15project.htm, accessed 18 April 2016. 
Piketty, T. (2013), Capital in the Twenty First Century (Cambridge, MA: Harvard University Press).

Purcell, J. (2014), 'Disengaging from engagement', Human Resource Management Journal, $24: 3,241-54$.

Purcell, J. and Georgiadis, N. (2007), 'Why should employers bother with worker voice?', in Freeman, R., Boxall, P. and Haynes, P. (eds), What Workers say; Employee Voice in the Anglo-American Workplace (Ithaca, NY: Cornell University Press).

Roche, W. and Teague, P. (2014), 'Successful but unappealing: fifteen years of workplace partnership in Ireland', International Journal of Human Resource Management, 25:6, 781-94.

Rubery, J. (2015a), 'Austerity and the future for gender equality in Europe', Industrial and Labor Relations Review, 68:4 715-41.

Rubery, J. (2015b), Re-regulating for inclusive labour markets, ILO Working Papers: Conditions of Work and Employment Series No. 65 (Geneva: International Labour Organization).

Rubery, J., Cooke, F., Earnshaw, J. and Marchington, M. (2003), 'Inter-organisational relations and employment in a multi-employer environment', British Journal of Industrial Relations, 41:2, 1100-222.

Rubery, J. and Fagan, C. (1995), 'Comparative industrial relations research: towards reversing the gender bias', British Journal of Industrial Relations, 33:2, 209-36.

Rubery, J. and Grimshaw, D. (2003), The Organisation of Employment: An International Perspective (London: Palgrave).

Rubery, J., and Urwin, P. (2011), 'Bringing the employer back in: Why social care needs a standard employment relationship', Human Resource Management Journal, 21:2, 122-37.

Schaufeli, W. (2014), 'What is engagement?' in Truss, K., Delbridge, R., Alfes, K., Shantz, A. and Soane, E. (eds), Employee Engagement: Theory and Practice (Abingdon: Routledge).

Stuart, M., Martinez-Lucio, M. and Robinson, A. (2011), “Soft regulation” and the modernisation of employment relations under the British Labour government (1997-2010); partnership, workplace facilitation and trade union change', International Journal of Human Resource Management, 22:18, 3794-812.

Taylor, P., Baldry, C., Danford, A. and Stewart, P. (2009), 'An umbrella full of holes? Corporate restructuring, redundancy and the effectiveness of the ICE Regulations', Relations Industrielle, 60:1, 27-49.

Van Wanrooy, B., Bewley, H., Bryson, A., Forth, J., Freeth, S., Stokes, L. and Wood, S. (2013), Employment Relations in the Shadow of Recession (Basingstoke: Palgrave Macmillan).

Wilkinson, A., Dundon, T. and Marchington, M. (2013), 'Employee involvement and voice' in Bach, S., and Edwards, M. (eds), Managing Human Resources (Chichester: John Wiley). 